\title{
Transport, Mobility and Mobile Groups in Bengal: Deconstructing Colonial Myths of Movement and Migration in the Eighteenth Century
}

\author{
Baijayanti Chatterjee \\ Assistant Professor of History, Seth Anandram Jaipuria College, Calcutta University. \\ Email: oooo-0oo3-1176-6557. Email: chatterjeebaijayanti@gmail.com
}

\begin{abstract}
This article sets out to dismiss the European notion of a lazy and static Bengali perennially averse to movement, by looking at transport networks, mobility and mobile groups in eighteenth century Bengal. The article argues that Bengali society was highly mobile, owing to the presence of an efficient system of transport by land and water which sustained movement. The so-called 'indolence' of the Bengali and his reluctance for movement was in fact a 'myth' created by the Europeans with a vested interest to disparage native society and to justify European domination over Bengal.
\end{abstract}

Keywords: Colonial myth-making, transport \& mobility, eighteenth-century Bengal

\section{Introduction}

Among the many European misconceptions about eighteenth century Bengal was the notion that the Bengalis were generally a race of indolent, stagnant people who were greatly averse to any kind of movement, lacked the spirit of discovery, and mostly preferred to be indoors in the shelter and safety of their homes. Such ideas originated in writings of early colonial officials like Scrafton and Orme and continued to colour the writings of colonial officials well into the nineteenth century. Thus Sherwill, in making a survey of the district of Dinajpur, in Bengal, writes: "They (the inhabitants of Dinajpur) have a great repugnance to go far from home, more especially to remain away from it at night. They seldom venture beyond the limits of their own or neighbouring villages, or the nearest market place or hat. If a man ventures a few miles beyond, on his return home he speaks of the "foreign land" he has visited... None...quit their country for service elsewhere" (Sherwill 1865: 9). Yet to accept this stereotypical image of the indolent and lazy Indian who was antipathetic to movement of any kind would not only be erroneous but would also induce us to wrongfully subscribe to a colonial myth perpetuated with a vested motive of legitimizing the dominance of a so-called strong and active race of Europeans over a class of weak and lethargic natives, ill-disposed to mobility and enterprise. This article attempts to dismiss the colonial myth of the lazy and the static native and his reluctance for movement by focusing on transport networks, mobility and mobile groups within the Province of Bengal in the eighteenth century.

\section{The Basis of Movement: The Transport Network}

\footnotetext{
(c) AesthetixMS 2020. This Open Access article is published under a Creative Commons Attribution Non-Commercial 4.o International License (http://creativecommons.org/licenses/by-nc/4.o/), which permits non-commercial re-use, distribution, and reproduction in any medium, provided the original work is properly cited. For citation use the DOI. For commercial re-use, please contact editor@rupkatha.com.
} 
Throughout the eighteenth century in Bengal there was a prodigious movement of both people and goods. The presence of an efficient transport network in Bengal primarily by means of its waterways facilitated the movement of people and trade and commerce (detailed information on transport networks in Bengal and their role in sustaining the economy of the Province can be obtained from Datta 1984; Deloche and Mitra 1991; Mukherjee 2010; 2013).The GangaBrahmaputra rivers, together with their tributaries and distributaries, criss-crossed the country and provided 'the most complete and easy inland navigation' (Rennell and Banks 1781: 87). Goods and people were transported from one part of the country to another in boats across these rivers. During the dry season, when the river waters subsided, a network of roads complemented the rivers. Nevertheless, in Bengal transport was essentially water-borne due to the Province's fluvial ecology. So far as speed of travelling was concerned one could cover as much as $80-110 \mathrm{kms}$ in a day going with the stream in the river Ganges (Deloche 1994: 176, Vol. 2). On the other hand an ordinary traveller travelling by road covered no more than 35 or $40 \mathrm{kms}$. per day (Deloche 1993: 286, Vol. 1). Thomas Bacon in his memoirs laments regarding his journey by a palanquin on land 'on account of the abominable shaking and the slow rate of progression.' 'The jog-trot' he complains averaged 'about four miles an hour' (Bacon: 1837: 125-127, Vol. 1) i.e. approximately 6 $\mathrm{km} / \mathrm{hr}$. James Long notes that roads were few in old Calcutta and transport was mainly by water for the purposes of trade as well as leisure (Long 1869: xxxii, Vol. 1). Since roads were scarce carriages were few and travelling by the palanquin was considered a luxury. The Barasat road was probably the oldest road in Calcutta and according to Long was probably kutcha as the expense of repairing the Barasat and Dum-Dum roads in 1752 was a mere Rs.20 (Long 1869: xxxii, Vol. 1). Therefore throughout the eighteenth century in Bengal transport by water was far more preferable than transport by land as the water route was speedier. The water route was also open to even the poorest villagers, because, the latter could construct a wide variety of rudimentary vessels capable of sailing in the Bengal rivers. For instance, in Hooghly a variety of boats called dongas were used which were in fact dug-outs that were 'scooped out from a single tree trunk e.g. mango, sal tree, cotton or palm' (O'Malley 1912:202) The dongas had a capacity of 3 to 20 maunds and could be as much as 30 feet in length and could carry more than 15 men. During floods 'temporary rafts made of three or four plantain stems' were used for crossing the rivers (O'Malley 1912:202). Such rudimentary vessels sustained mobility and these could be built by every villager at least possible cost for moving to and fro between the village and the market.

So far as security of the travellers on the roads and rivers was concerned, in the hay days of the Nizamat robberies were very uncommon, the Riyaz-us-Salatin eulogises on the peace and order under the Nizamat at the time of Murshid Quli Khan (Ghulam Husain Salim 1902: 278-79). While the faujdar under the Mughal system of administration was required to maintain law and order he was to do so with the help of the zamindars (local landholders). Moreover by the custom of the country, the zamindars in whose zamindari a robbery had been committed was required to make good the loss. Hence it was in the interest of the zamindar to maintain law and order within his jurisdiction. Thus Scrafton elaborating on the customs and usages of Hindostan writes:

And so free is the country from robbers that I doubt there having been an instance of one in the memory of man. The diamond merchants, who generally pass this country, have seldom even a weapon of defence, owing to that admirable regulation, which obliges the Lord of that spot where the robbery is committed, to recover the effects, or make good the value. (Scrafton 1758: 12)

However after the battle of Plassey, there was a decline in the authority of the Bengal Nawabs and the zamindars began to assert their independence. The faujdari institution gradually declined and 
the zamindars without any fear of interference from the centre neglected their police duties (Akhtar 1982:134-135). The situation did not improve under Company administration. As a result the security on roads for travellers greatly deteriorated. There were frequent reports of dacoities from all parts of the Bengal countryside. ${ }^{\text {ii }}$ Travellers were generally allowed to carry arms with them for their own protection. However by an order of 1773 the Company forbade all travellers from carrying arms and issued a public notice that 'all persons or bodies of Men traveling armed

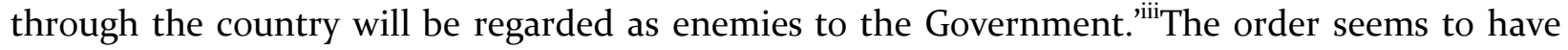
caused considerable inconvenience to travelers. It was therefore revoked and a new order passed whereby 'all merchants and others traveling on lawful business [were] to be permitted to carry arms. ${ }^{\text {,iv }}$ Only the sanyasis, whose incursions in the Bengal countryside had become very alarming (see section 2.2) were forbidden from carrying arms. ${ }^{\mathrm{v}}$

Inspite of deteriorating conditions of law and order on the roads and rivers, the presence of an efficient and speedy transport network, accessible to all, facilitated movement. While trade and commerce was the primary incentive for long distance journeys yet people traveled for many other reasons than trade and commerce. The following section looks at the causes which influenced mobility in Bengali society in the eighteenth century.

\section{Mobility in Eighteenth Century Bengal}

Prior to the rise of the Company as the highest political authority in Bengal, the Nawabs belonging to the family of Murshid Quli Khan ruled over the Province. This ruling class of Nazims was also quite mobile and moved about the entire country on hunting expeditions or for military operations. The hunt as already indicated by the Mughal historian Abul Fazl in the sixteenth century did not simply involve a wanton slaughter of wild animals (Abul Fazl Allami 1997: 292, Vol. 1) but it was a means for the ruler to tour the country and gather intelligence. ${ }^{\text {vi }}$ It also kept the military well drilled. The successor states of the Mughals like the Nizamat in Bengal generally followed the Mughal customs and used hunting as a means to remain mobile and gather intelligence. Aliverdi Khan for instance was extremely fond of the sport (Seid Gholam HosseinKhan 1789: 400, Vol. 1). During the time of Aliverdi Khan the Marathas kept on attacking Bengal and it became essential for the Nawab to tour the country and gather intelligence about any impending attack by the Marathas. The Nazims of Bengal were therefore bold, active and mobile keeping themselves aware and prepared for all eventualities within their kingdom.

When the East India Company became the administrator of the Province following the battles of Plassey (1757) and Buxar (1764), the Nawabs merely remained as titular heads and it was the Company administrators and officials who moved about and penetrated the different parts of Bengal. Some of these tours were administrative exercises in the form of carrying out surveys, gathering data for administrative purposes while some represented efforts to comprehend the customs and culture of a new country. In 1764 Major James Rennell was employed to make a survey of the Ganges delta 'with a special object in view of finding a shorter passage suitable for large vessels from the Ganges to Calcutta, than that through the Sunderbans and the Meghna' (La Touche 1910:3). He was also instructed by Governor Vansittart to 'keep a very particular Journal' of his Proceedings, 'noting the Appearance and Produce of the Countries' through which he passed and record 'the name of every Village, \& whatever else may seem remarkable...' (La Touche 1910: 9). In the early part of the nineteenth century a large number of surveys made by English officials were published. These surveys may therefore have commenced towards the end of the eighteenth century. To rule an alien land and collect its revenues the Company needed 
information and these surveys were initiated and carried out even in the very remote corners of the Bengal Province. In 1831 Captain Pogson's survey of Chittagong was published giving a detailed account of his journey to that place and the physical features, the flora and fauna of Chittagong and the revenues generated by the country (Pogson 1831). In 1840 was published Taylor's survey of Dacca (Taylor 1840). In 1871 James Westland former Magistrate and Collector of Jessore published his survey of the country (Westland 1871) and in 1876 Magistrate and CollectorH. Beveridge's survey of Bakarganj came out (Beveridge 1876) and finally W.W. Hunter came out with his voluminous Statistical Account of Bengal based on his elaborate survey of the Bengal Province (Hunter 1875-77). For making these surveys the surveyors for the purpose of collecting information must have made local enquiries which would induce them to travel throughout the length and breadth of the region under their survey. While the necessity of making surveys and knowing the country imposed the need for extensive movement among the Company officials a second reason for travel by Europeans was the desire to study and understand the people that they governed. Bishop Heber's account of his journey in Bengal reflects a sense of curiosity on the part of the author in knowing and understanding the ways of the natives (Heber 1928). Again in Thomas Bacon's First Impressions we find an attempt to truthfully understand and depict a country where to use the author's own words, 'the scenery, objects, and people are so different from those in Europe' (Bacon 1837 : vi, Vol. 1)

While the European in Bengal was highly mobile for reasons of administrative necessity and curiosity, the native Bengali was also on the move. Movement of the people for diverse reasons is in fact a recurrent theme in Bengali literature and folk tales (for a complete collection of Bengali folk tales consider Day 1912). In the folk tales Princes moved for the spirit of adventure and Brahmins traveled in order to collect alms from rich people during weddings and funerals. In Bharatchandra's Vidya Sundar (the second portion of the poetic work Annadamangal or "Eulogy of the food-giving Goddess" written in 1752-53) the prince Sundar traveled from the far land of Kanci to Burdwan to see the princess Vidya after a messenger informed the prince Sundar of her beauty. The journey from Kanci to Burdwan took about 6 months but the prince Sundar with his wishing-horse covered it in 6 days (Bharatchandra 1963: 29-31). Thus the literature from the Bengal countryside reflects a society always on the move.

In the eighteenth century the raison d'être for movement was trade and commerce. From Dinajpur in the north to Bakarganj in the south grain traders bought rice from different parts of the Bengal Province and sold these in the Calcutta markets. Bakarganj rice was famous in the markets of Calcutta, where it was known as balam rice, from the balam country boats in which it was generally carried (Jack 1918:51). Not just rice, salt, fishes, betel-nuts, wood and the trade of many other commodities were carried by means of boats along river routes. This extensive trade and commerce forced merchants to remain mobile. J.C. Jack in his survey mentions that in the district of Bakarganj there was 'a wandering gipsy tribe mostly Muslims who lived in boats.' These river-gypsies lived primarily by woodcutting, fishing and peddling and were 'peaceful, industrious, orderly and honest' (Jack 1918: 33). In Bakarganj there was also a class of itinerant woodcutters called baulis who 'live in ordinary boats, while they carry the wood in strong open boats called baulia boats' (Jack 1918: 81). The woodcutters went to the Sundarban forest in January and remained there until April or May returning with their cargo of timber.

Apart from traders, peasants were also quite mobile. The pahi-kasht peasants were so characterized because of their movement. ${ }^{\text {vii }}$ Peasants also deserted their lands and migrated elsewhere if unfair treatment was meted out to them or the revenue demands of the state became exorbitant (Table 1). 


\begin{tabular}{|l|l|}
\hline $\begin{array}{l}\text { An Account of the Ryotts deserted from the following parganas in the } \\
\text { Province of Nadia during the Bengal year } 1188(1781-82)\end{array}$ \\
\hline Parganas & Number of families \\
\hline Ookra & 306 \\
\hline Huldeah & 288 \\
\hline Pagenour [sic] & 194 \\
\hline Maamjewan & 148 \\
\hline Matiaree & 1246 \\
\hline Baugwan & 859 \\
\hline Soonapore & 61 \\
\hline Munseebpore & 544 \\
\hline
\end{tabular}

Source: Committee of Revenue, $1^{\text {st }}$ April 1782 to $29^{\text {th }}$ April 1782, Appendix for April 1782.

Glazier points out that the ryotts of Cazeerhat were in the habit of going to Calcutta to make complaints if they were ill-treated in any special degree (Glazier 1873: 22-23). During the insurrection of 1783 in Rangpur the ryotts displayed surprising mobility. The ryotts of chaklas ${ }^{\text {viii }}$ Cazeerhat, Kankina, and Fattehpore, rose in rebellion in 1783 and these insurgents also forced the ryotts of Cooch Behar to join them, and sent parties into Dinajpur to bring over the people there (Glazier 1873: 21).

Natural disasters also led to large-scale movement of people. When natural calamities like a flood or a drought occurred populations of the affected areas became mobile as they migrated to regions that had not been hit by the calamity. The southern and eastern parts of Bengal were more affected by floods than drought while the northern and western region of Bengal suffered more from drought than floods. Hence when a flood hit south-east Bengal people migrated towards the north whereas when severe drought hit north or west Bengal people migrated towards the south and the east. For instance in the famine of 1769-70 eastern Bengal was very little affected hence peasants from the areas where the drought was more severe migrated to eastern Bengal. But in flood-induced famine of $1787-8$ eastern Bengal was very severely affected while parts of northern Bengal were not as much affected as eastern Bengal hence there was a movement of people from eastern to northern Bengal (Datta 2000: 268-71). People therefore considered movement and migration as an effective strategy of survival during such times of crisis (Datta 2000: 268).

Geographical mobility was also induced by social occasions such as marriages. The marriages in the zamindari households were a grand affair. People from far and near came to attend the wedding. Thus the mother of Maharajah Tej Chund in her petition to the Company for providing her with funds to defray the costs of her son's wedding pointed out:

...at a marriage of this kind it is the indispensable custom to send invitations accompanied by Presents to the Rajahs, Zamindars ... of Bengal and the People of Rank 
both far and near for all of whom entertainment and presents must be prepared, Provision must be also made for others who will come uninvited...as the Burdwan Family by the blessing of God bears an honorable name in the books of fame, people will assemble on this occasion from all quarters... [Emphasis ours] ${ }^{\mathrm{ix}}$

In Faridpur, the cultivator for the purpose of diversion 'during the dull season of July to September' often paid a social visit to his friends and relatives in other villages. This custom was more common amongst Muslims than Hindu villagers. On these visits the cultivator generally took his entire family with him in a boat which was 'somewhat larger than the dinghy and must usually be hired', although many of the more prosperous cultivators possessed one (Jack 1916: 46). In the district of Bakarganj there were generally 15 boats amongst every hundred families, 'but rather more in Gaurnadi, Jhalakati and Patuakhali thanas and as many as 33 in Swarupkati thana with its large area under marsh' (Jack 1918: 57).

Pilgrimage was another reason for long-distance travel and was undertaken by the elite as well as the common man. Pilgrims traveled not only within the province- to Gangasagar, Tarapur, Vakresvara, and to the temples of Nadia and Birbhum but also to Puri in Orissa and Mathura, Vrindavan, Allahabad, Gaya, Banaras and Haridwar ( Mukherjee 2013: 93-94). Tilottama Mukherjee has shown that the movement of the pilgrims also generated revenue for the state (Mukherjee 2013:104). Pilgrimages were generally financed by the wealthy and were joined by many others who desired to visit the places of pilgrimage but did not have enough means. Bijayaram Sen's Tirthamangal gives an account of the pilgrimage made by the zamindar Krishnachandra Ghosal around 1769 (Sen 1915). Krishnachandra had a very large party of pilgrims some of whom belonged to his own village and some who had joined him on the way like the author Bijayaram Sen himself. ${ }^{x}$

\subsection{Women's Mobility}

Perhaps the only section of the society whose movement was in any way restricted were women. Such restrictions were imposed as a result of the custom which forbade respectable women from appearing in public. On the seclusion practiced by the women of Bengal, H. Beveridge in his survey of Bakarganj writes:

...few Bengali women of respectability will consent to appear before strangers. The part of the house she inhabits is that farthest away from publicity, and is called emphatically the 'inner place.'.... When she is obliged to give evidence or to hold any communication with a stranger, she does so from behind a curtain or from within a covered palanquin. Some affect to be still more particular, and will not hold direct communication with any man, even though a curtain be hung between them. Such ladies insist upon the conversation being carried on through the intervention of a third party, generally a female servant, who carries the questions and answers from one to the other... (Beveridge 1876: 226-227)

How then did the women observing seclusion travel? The practice of seclusion obviously limited the movement of women of high birth but it would be wrong to surmise that women belonging to such noble families always remained confined indoors. On the mode of travelling by ladies of high-birth Beveridge observes:

When a native lady has occasion to travel, she does so in a covered palanquin or litter, or in a boat. Sometimes she travels on an elephant, the howdah being carefully covered 
over ... Of course no native lady ever thinks of riding on horseback, and next to their dancing with other men than their husbands, nothing in the conduct of our country women seems to surprise them so much as their riding (Beveridge 1876: 227).

European women were of course more mobile than their Indian counterparts. European ladies often took an arduous voyage to India at a very young age in the lookout for a prospective suitor. In India since the number of European men greatly outnumbered the number of European ladies, women migrating from Europe upon their arrival in the colony were immediately 'besieged by suitors.' In 1671, the English East India Company paid for the passage of 20 women who were willing to come to India to marry the Company's employees. In 1753 sixteen year old Margaret Maskelyne after undertaking a formidable journey to India in a tiny ship called the Godolphin married Robert Clive (De Courcy 2013: 9), who turned the fortunes of the Company at the battle of Plassey (1757). These young women migrating to India 'displayed the courage and adventurous readiness to take risks' that also characterized their male counterparts. Many European women in India like the 'indefatigable wanderer' (Goldsworthy 2018: 131) Fanny Parkes ${ }^{\mathrm{xi}}$ also turned out to be a prolific traveler and an enthusiastic collector. However not all European women became adventuresses. Those blessed with beauty and high birth did not embark upon an onerous voyage to an alien land to face unknown possibilities and challenges.

In contrast to the European women in India, the native women's movement was largely constrained. Beveridge opines that the only time a native lady 'has a chance of seeing the world' is when she goes on a pilgrimage and that was the reason behind the popularity of pilgrimages to Hardwar or to Puri. According to Beveridge many rich old women went to the Ganges or to Kamrup for much the same reason that rich women in England went to Brighton or Homburg (Beveridge 1876: 227).

Yet with regard to the women of Bengal, Abul Fazl the Mughal historian writing in the sixteenth century, makes a curious remark. He says, 'The people [of Bengal] are submissive and pay their rents duly...the chief public transactions fall to the lot of women' (Abul Fazl Allami 1997: 134, Vol. 2). Writing in the mid-nineteenth century, Sherwill makes another curious remark that on the approach of Europeans, the native men generally concealed themselves in their villages and ceded to their wives 'the dreaded duty of having to reply to the interrogatories of European strangers' (Sherwill 1865: 9). Bolstering the myth of the lazy and the timid native Sherwill points out that he had witnessed an 'able-bodied man, when required to show the way from his own to the adjoining village, call loudly upon his aged mother to accompany and protect him' (Sherwill 1865: 9).

Therefore it seems that the seclusion of Bengali women and restrictions on their mobility was not universal. The principle of seclusion would perhaps be more rigidly adhered to by women of the wealthier classes while women who belonged to the poorer classes could not afford to adhere to the strict policy of seclusion and remain confined within the household for 'they must go to the tank or the well to draw water, and they have to go on foot if they want to visit a temple or witness a religious ceremony' (Beveridge 1876: 228).

\section{Mobile Groups: The Sanyasis and Fakirs of Bengal}

While mobility was a characteristic feature of all sections of people in society certain groups of people were more mobile than others. The sanyasis (Hindu recluses) and fakirs (Muslim holy men) for instance were a very mobile body of men. Nitin Sinha has pointed out that 'while the image of the indolent native who could be induced to move only by necessity thrived as typical 
throughout the early phase of colonial rule, in fact there existed a diverse range of mobile people and groups of which the Company-state was well aware' (Sinha 2013:117). Sinha draws our attention to activities and movements of peripatetic groups such as the sanyasis in Bihar and Bengal whose 'very mobility made the Company state anxious' (Sinha 2013:117). Warren Hastings in fact considered the sanyasis as the 'gypsies of Hindostan.' In a letter dated $9^{\text {th }}$ March 1773 Hastings gave the following description of the sanyasis:

The history of the people [sanyasis] is curious. They inhabit or rather possess the country lying south of the hills of Thibet [Tibet], from Cabul to China. They go mostly naked...rove continuously from place to place, recruiting their number with the healthiest children they can steal in the country through which they pass...They are hardy, bold and enthusiastic to a degree surpassing credit. Such are the sanyasis, the gypsies of Hindustan (Sachse 1917: 28).

From Hastings description it would transpire that the sanyasis of Bengal were not recluses who had withdrawn themselves from worldly affairs. They rendered military services to many regional powers (Sarkar: 54). The Sanyasis were of two categories - resident and mobile. In Bengal the resident sanyasis held rent-free land tenures in Mymensing, Dinajpur, Malda and Rangpur (Dasgupta 1992: 32). Some of the resident sanyasis also engaged in usury - a practice which was greatly resented by the Company administration. ${ }^{\text {xii }}$ Besides these resident sanyasis roving bands of sanyasis travelled all over the Bengal countryside levying contributions over the inhabitants of the village through which they passed. Apart from the sanyasis bands of Muslim fakirs too roamed about the Bengal countryside levying contributions over villages in the area through which they passed. These Muslim fakirs like the sanyasis were itinerant groups of people who had travelled far and wide. Bishop Heber records his meeting with one of these wandering religious mendicants thus:

In the course of our halt this day a singular and painfully interesting character presented himself in the person of a Mussulman Fakir...He asked my leave to sit down on the bank to watch what we were doing, and said it gave his heart pleasure to see Englishmen; that he was a great traveler, had been in Bombay, Kabul \&c. and wanted to see all the world, wherein he was bound to wander as long as it lasted (Heber 1828: 157 Vol. 1).

The sanyasis carried out their raids in Bengal in the districts of Malda, Dinajpur, Rangpur, Cooch Behar or in other parts of eastern Bengal by using the rivers Ganga, Kushi, Gandak. (Bhattacharyya 2014: 87-88). In 1773 the sanyasi incursions were reported as far as at Chittagong. ${ }^{\text {xii }}$

\section{'The Myth of the Lazy Native': Dismissing the Idea of a Static Bengali}

From the above discussion it would appear that the Europeans entertained a false notion of an indolent native who was forever averse to movement. Indian society was highly mobile in the eighteenth century (Table 2).

\begin{tabular}{|c|c|c|c|c|}
\hline Mobile Groups & $\begin{array}{l}\text { Number of } \\
\text { People } \\
\text { Moving }\end{array}$ & Cause of Movement & Year & References \\
\hline $\begin{array}{l}\text { Agricultural } \\
\text { Population (Ryotts of }\end{array}$ & $\begin{array}{l}3,446 \\
\text { families }\end{array}$ & $\begin{array}{l}\text { Desertion (probably on } \\
\text { account of a rise in }\end{array}$ & $1781-82$ & $\begin{array}{l}\text { Committee of Revenue, } \\
1^{\text {st }} \text { April } 1782 \text { to } 29^{\text {th }} \text { April }\end{array}$ \\
\hline
\end{tabular}


Transport, Mobility and Mobile Groups in Bengal: Deconstructing Colonial Myths of Movement and Migration in the Eighteenth Century

\begin{tabular}{|c|c|c|c|c|}
\hline Nadia) & & $\begin{array}{l}\text { revenue demand or ill- } \\
\text { treatment by revenue } \\
\text { collectors). }\end{array}$ & & $\begin{array}{l}\text { 1782, Appendix for the } \\
\text { month of April } 1782 \text {. }\end{array}$ \\
\hline $\begin{array}{l}\text { Non-Agricultural } \\
\text { Population } \\
\text { (Cultivators of } \\
\text { Mulberry Grounds in } \\
\text { Lushkerpore) }\end{array}$ & 2091 families & $\begin{array}{l}\text { Desertion on account of } \\
\text { the great famine of } \\
1769-70 .\end{array}$ & 1770 & $\begin{array}{l}\text { Committee of Circuit: } \\
\text { Kasimbazar, } 25^{\text {th }} \text { August } \\
1772 .\end{array}$ \\
\hline Pilgrims & $\begin{array}{l}\text { 10,ooo people } \\
\text { (approx.) }\end{array}$ & $\begin{array}{l}\text { Pilgrimage from Bengal } \\
\text { to Deoghar }\end{array}$ & 1789 & Mukherjee 2013: 99. \\
\hline Itinerant Sanyasis & 1500 & $\begin{array}{l}\text { Levying contributions } \\
\text { in the localities of the } \\
\text { Dacca Province }\end{array}$ & 1771 & $\begin{array}{l}5^{\text {th }} \text { February } 1771 \text {, Letter } \\
\text { of the Supervisor of } \\
\text { Dacca Thomas Kelsall to } \\
\text { Samuel Middleton at } \\
\text { Murshidabad, } \\
\text { Proceedings of the } \\
\text { Controlling Council of } \\
\text { Revenue, Murshidabad. }\end{array}$ \\
\hline Itinerant Fakirs & 2,000 & $\begin{array}{l}\text { Travelling to Dinajpur } \\
\text { by way of Purnea } \\
\text { levying contributions. }\end{array}$ & 1770 & $\begin{array}{l}7^{\text {th }} \text { December } 1770 \text {, Letter } \\
\text { of the Supervisor of } \\
\text { Dinajpur, H. Cottrell, to } \\
\text { Richard Becher at } \\
\text { Murshidabad, } \\
\text { Proceedings of the } \\
\text { Controlling Council of } \\
\text { Revenue Murshidabad. }\end{array}$ \\
\hline
\end{tabular}

An efficient transport network sustained and bolstered movement and a mobile society. The characterization of Indians as lazy and indolent and physically inferior to the European by Company officials like Orme or Scrafton was no doubt made to justify colonial domination. From laziness followed the averseness towards movement and long journeys. And yet when Rennell was making his survey of Bengal on the frontier of Kuch Bihar he met with a party of sanyasi-fakirs who too had travelled that far (La Touche 1910: 3). This 'myth of the lazy native' was not just applied in case of the Indian. The British image of the Malays in the $19^{\text {th }}$ and the $20^{\text {th }}$ centuries was similarly coloured. José Rizal, the Filipino nationalist and the 'Asian apostle of racial equalitarianism' (Fisher 1956: 259) in his essay La Indolencia de los Filipinos (The indolence of Filipinos, 1890) expostulated with the characterization of Filipinos as lazy and indolent. In this essay Rizal concluded that the so-called 'indolence' of the Filipinos was the result of misgovernment and of backwardness under colonial dominance. Rizal 'painstakingly examined historical records and marshaled many pages of evidence to prove that before the Spanish conquest the Filipinos were a hardy, industrious, and ambitious people' (Fisher 1956: 262). But prolonged subjection to colonial dominance had tethered their initiative and industry. Syed Husain Alatas, the Malaysian sociologist and author in his book The Myth of the Lazy Native explained at length as to why the Europeans made allegations of laziness and indolence against natives of maritime south-east Asia. According to Alatas 'a negative image of the natives and their society' was created by the 'myth of the lazy native' to justify and rationalize European conquest 
and domination' and to also 'justify compulsion and unjust practices in the mobilization of labour in the colonies' (Alatas 1977: 2). Alatas argues that the myth of the lazy native was created because the Malays, the Javanese or the Filipinos refused to supply labour for what Alatas calls 'colonial capitalism. ${ }^{\text {xiv }}$ In case of India as well the myth about the lazy and indolent native was applied to denigrate indigenous society and justify colonial domination. The Indian, particularly the Bengali, was portrayed as extremely lazy and out of this habitual laziness he was greatly averse to movement and undertaking long journeys. This article has attempted to deconstruct the myth of the 'lazy native' and his aversion to movement in the context of Bengal by showing how mobile Bengali society was in the eighteenth century.

\section{Acknowledgement}

The author would like to thank her Supervisor Prof. Rajat Datta at the Centre for Historical Studies, Jawaharlal Nehru University, for his comments, suggestions and corrections on her thesis of which this article is a part.

\section{Notes}

iSee for instance Scrafton (1763) who writes: "The Gentoos (Hindus) of the lower provinces are a slightmade people. Rice is their chief food; and it seems to afford but poor nourishment, for strong robust men are seldom seen among them... Is nature then deficient? Surely not... We must rather look for it in ...their sedentary way of life and in Bengal and the conquered provinces in the dejected state of their minds...No wonder then, that with such customs, such bodies and such minds, they fall an easy prey to every invader.' This idea of the lackadaisical and lethargic native lacking courage and competence to match his European counterpart is further elaborated and explicated in writings of other early colonial official like Robert Orme (1763). Again on the laziness of the well-to-do native Thomas Bacon (1837) in his First Impressions writes : 'The moment a native is rich enough to afford to be lazy, he at once forbears to exert himself personally, and pays another man to do his work for him ; he builds a temple or a ghat, to gain himself a name...and then he seats himself upon his haunches for the remainder of his existence...having nothing in the world to do but to stuff himself with curry, rice, and ghee (clarified butter)...'

${ }^{\text {ii }}$ For frequent incidents of dacoity in eighteenth century Bengal see the twelve volumes of the Proceedings of the Controlling Council of Revenue at Murshidabad, (1919-1924) and The Letter Copy Books of the Resident of the Durbar at Murshidabad (1919).

iii $21^{\text {st }}$ January1773, Letter from J. Stewart at Fort William to Mr. Charles Bentley, Collector at Chittagong, Chittagong Records: Letters Received, $9{ }^{\text {th }}$ January to $30^{\text {th }}$ December 1773.

${ }^{\text {iv }} 11^{\text {th }}$ March 1773, Letter from J. Stewart at Fort William to Mr. Charles Bentley, Collector at Chittagong, Chittagong Records: Letters Received, $9^{\text {th }}$ January to $30^{\text {th }}$ December 1773.

${ }^{v} 1^{\text {th }}$ March 1773, Letter from J. Stewart at Fort William to Mr. Charles Bentley, Collector at Chittagong, Chittagong Records: Letters Received, $9^{\text {th }}$ January to $30^{\text {th }}$ December 1773.

${ }^{v i}$ In the Ain-i-Akbari, Abul Fazl, the court-historian of Akbar, writes about the true purpose of the hunt. Abul Fazl notes: 'Superficial worldly observers see in killing an animal a sort of pleasure...But deep inquirers see in hunting a means of acquisition of knowledge...This is the case with His Majesty. He always makes hunting a means of increasing his knowledge, and besides, uses hunting parties, as occasions to inquire, without having first given notice of his coming, into the condition of the people and the army. He travels incognito, and examines into matters referring to taxation...Short-sighted and shallow observers think that 
His Majesty has no other object in view but hunting, but the wise and experienced know that he pursues higher aims.'

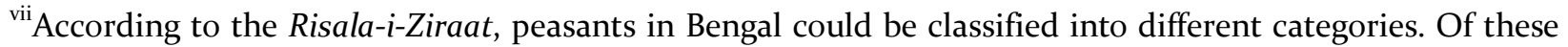
the khud-kasht (self-cultivating) agriculturist resided in the pargana where he cultivated the land; on the other hand the paikasht cultivators resided in a village other than the one in which their field was located. The pahi-kasht peasantry were therefore a mobile group of cultivators who constantly moved between their home and the plot of land which they cultivated. A translation of the Risala-i-Ziraat can be found in Mukhia (1993).

viii Chaklas are smaller administrative divisions under the Province.

${ }^{\text {ix }}$ Letter from the mother of Maharajah Tej Chund to the Company, $26^{\text {th }}$ October 1775 , Proceedings of the Provincial Council of Revenue at Burdwan.

${ }^{x}$ Pilgrimages in eighteenth century Bengal were not just an act of piety but were also an expression of the curiosity of the people (Mukherjee 2013:109). Bijayram Sen's Tirthamangal (1915) that describes the pilgrimage of Krishnachandra Ghosal, shows how the latter's party of pilgrims en route to Kasi not only visited places that were known for their religious significance but also visited places of historical interest like the spot where the Nawab Siraj-ud-doulah was betrayed by a fakir or where the forces of Mir Qasim fought with the English troops. Moreover Krishnachandra Ghosal's younger brother Goculchandra was employed by Governor Verelst. Therefore it has been interpreted that Krishnachandra Ghosal's pilgrimage was not only inspired by motives of piety but to seek the opinion of the common people and of important personages about British rule. Indeed during his tirthayatra (pilgrimage) Krishnachandra met some of his very important contemporaries like Raja Shitab Rai in Patna.

${ }^{x i}$ Fanny Parkes is the celebrated author of the book Wanderings of a Pilgrim in Search of the Picturesque that recounts her travels in India (Goldsworthy 2018: 131-152).

xii Glazier in his survey of Rangpur (1873) record the letter of one Mr. John Eliot who in a report to the Board in September 1789 gave a very unfavourable account of the money-lending practices of the Sanyasis thus: 'Three years' residence in these districts has given me opportunities of hearing many things of the conduct of these Sanyasies...They call themselves fakers... but their real profession is that of usury, and having the command of cash, they let it out at interest... At the stated times the interest is demanded. If he has no cash, his child is confined to oblige him to pay the money, and sometimes sold... Complaints of the daring acts and cruelties of these Sanyasis must have frequently reached the Collectors of these districts, if these people had not contrived by arts, threatenings, and severities to suppress them...'

xiii ${ }_{20}{ }^{\text {th }}$ February 1773, Letter from F. Law, Acting Chief at Dacca to Henry Walter, Acting Chief at Chittagong,

Chittagong Records: Letters Received, $9^{\text {th }}$ January to $30^{\text {th }}$ December 1773.

${ }^{\text {xiv }}$ For Alatas' view and a more comprehensive discussion on ideas of race and domination among early colonial officials refer to my paper 'Climate, Race, Domination: Environment and Imperialism in Early Colonial India' presented at $78^{\text {th }}$ session of Indian History Congress, Kolkata, 2017.

\section{References}

Akhtar, Shirin (1982): The Role of Zemindars in Bengal 1707-1772, Dacca, Asiatic Society of Bangladesh. Alatas, Syed Hussein (1977), The Myth of the Lazy Native: A Study of the Image of the Malays, Filipinos and Javanese from the $16^{\text {th }}$ to the $20^{\text {th }}$ century and its Function in the Ideology of Colonial Capitalism, London, Frank Cass Publishers.

Allami, Abul Fazl (1997), Ain-i-Akbari vol. ii, tr. H. S. Jarrett, New Delhi, Low Price Publications. 
Bacon, Thomas (1837): First Impressions and Studies from Nature in Hindostan, vol. 1, London, Wm. H. Allen \& Co.

Beveridge, H. (1876): The District of Bakarganj: Its History and Statistics, London, Trubner \& Co., Ludgate Hill.

Bhattacharyya, Ananda (2014): 'Sannyasi and Fakir Rebellion in Lower Bengal', The Calcutta Historical Journal, vol. xxx, No 1-2, pp. 85-102.

Chittagong Records: Letters Received, $9{ }^{\text {th }}$ January to $30^{\text {th }}$ December 1773 , West Bengal State Archives (WBSA), Kolkata.

Committee of Circuit: Kasimbazar $20^{\text {th }}$ August to $17^{\text {th }}$ September 1772, WBSA, Kolkata.

Committee of Revenue, $1^{\text {st }}$ April 1782 to $29^{\text {th }}$ April 1782 , WBSA, Kolkata.

Courcy, Anne De (2013): The Fishing Fleet: Husband Hunting in the Raj, London, Orion Publishers.

Dasgupta, Atis K. (1992): The Fakir and Sannyasi Uprisings, Calcutta, K.P. Bagchi \& Co.

Datta, Rajat (2000): Society, Economy and the Market: Commercialization in Rural Bengal c. 1760-180o, Delhi, Manohar.

Day, Rev. Lal Behari (1912): Folk Tales of Bengal, London, Macmillan.

Deloche, Jean (1993): Transport and Communication in India Prior to Steam Locomotion, vol. 1, Land Transport, tr. James Walker, Delhi, Oxford University Press.

(1994): Transport and Communication in India, Prior to Steam Locomotion, vol. 2 Water Transport, Delhi, Oxford University Press.

Dimock Edward C. Jr. (1963): The Thief of Love: Bengali Tales from Court and Village, Chicago, University of Chicago Press.

Firminger, W.K. (1919-1924): Proceedings of the Controlling Council of Revenue at Murshidabad, vols. 1-12, Calcutta, Bengal Secretariat Book Depot.

Firminger, W.K. (1919): The Letter Copy Books of the Resident of the Durbar at Murshidabad 1769-1770, Calcutta, Bengal Secretariat Book Depot.

Fisher, Marguerite J., (1956): 'José Rizal: Asian Apostle of Racial Equalitarianism', The Journal of Modern History, Vol. 28, No. 3, pp. 259-265.

Glazier, E.G., (1873): A Report on the District of Rungpore, Calcutta, Calcutta Central Press Company Limited.

Heber, Bishop (1828): Narrative of a Journey through the Upper Provinces of India from Calcutta to Bombay 1824-25, vol.1, Philadelphia, Carey, Lea \& Carey.

Hunter, W.W. (1875-77): A Statistical Account of Bengal, London, Trubner \& co.

Jack, J.C. (1916): The Economic Life of A Bengal District: A Study, Oxford, Clarendon Press. (1918): Bengal District Gazetteers: Bakarganj, Calcutta, Bengal Secretariat Book Depot.

Khan, Seid Gholam Hossein (1789): Seir Mutakherin tr. Nota-Manus, vol. 1, Calcutta, James White.

La Touche T.H.D. ed. (1910) : The Journals of Major James Rennell First Surveyor General of India Written For The Information Of The Governors Of Bengal During His Surveys Of The Ganges and Brahmaputra Rivers 1764 to 1767 , Calcutta, The Asiatic Society.

Long, Revd. J. (1869): Selections from Unpublished Records of Government for the Years 1748 to 1767 inclusive relating mainly to the Social Condition of Bengal with a map of Calcutta in 1784, Calcutta, Office of Superintendant of Government Printing.

Mukherjee Tilottama (2010): 'Of Rivers and Roads: Transport Networks and Economy in EighteenthCentury Bengal' Yogesh Sharma ed. Coastal Histories: Society and Ecology in pre-Modern India, Delhi, Primus.

(2013): Political Culture and Economy in Eighteenth Century Bengal: Networks of Exchange, Consumption and Communication, New Delhi, Orient Blackswan.

Mukhia, Harbans (1993): Perspectives on Medieval History, Delhi, Vikas Publishing House.

O'Malley, L.S.S. and Monmohan Chakravarti (1912): Bengal District Gazetteers: Hooghly, Calcutta, Bengal Secretariat Book Depot.

Pogson, WR (1831): Captain Pogson's narrative during a tour to Chateegaon, Serampore, Serampore Press. 
Proceedings of the Provincial Council of Revenue at Burdwan, $1^{\text {st }}$ September to $30^{\text {th }}$ October 1775 , WBSA, Kolkata.

Sachse, F.A. (1917): Bengal District Gazetteer: Mymensingh, Calcutta, Bengal Secretariat Book Depot.

Salim, Ghulam Hussein (1902): Riyaz-us-Salatin, tr. Maulavi Abdus Salam, Calcutta, The Asiatic Society.

Scrafton, Luke (1770): Reflections on the Government of Indostan with a short Sketch of the History of Bengal, London, reprinted by W. Strahan Ivn.

Sen, Bijayrama (1915): Tirthamangala, ed. by Nagendranath Basu, Calcutta, Bangiya Sahitya Parishad.

Sherwill, J.L. (1865): Geographical and Statistical Report of the Dinagepore District, Calcutta, Bengal Central Press.

Sinha, Nitin (2013): Communication and Colonialism in Eastern India, Bihar, 176os-188os, Delhi, Anthem.

Taylor, James (1840): A Sketch of the Topography and Statistics of Dacca, Calcutta, G.H. Huttmann, Military Orphan Press.

Westland, J. (1871): A Report on the District of Jessore: Its Antiquities, Its History and Its Commerce, Calcutta, Bengal Secretariat Office.

Baijayanti Chatterjee is currently employed as Assistant Professor of History at Seth Anandram Jaipuria College, Calcutta University. She completed her PhD (2018) from Centre for Historical Studies (CHS), Jawaharlal Nehru University (JNU). 